\title{
SYNTHETIC STRATEGY FOR THE PREPARATION OF BIOACTIVE GALACTOGLYCEROLIPIDS
}

\author{
Emiliano Manzo*, Maria Letizia Ciavatta, Dario Pagano and Angelo Fontana. \\ Institute of Biomolecular Chemistry (National Council of Research), via Campi Flegrei 3-80078, Pozzuoli \\ (Naples-Italy).Email: emanzo@icb.cnr.it
}

\begin{abstract}
The current communication represents an extended abstract of the presentation delivered on the joint Moldo-Italian seminar "New frontiers in natural product chemistry", held in the Institute of Chemistry, Academy of Sciences of Moldova on 30 September. A simple and efficient strategy for the synthesis of galactoglycerolipids is provided.
\end{abstract}

\section{Introduction}

Glycolipids, carbohydrate-linked lipids, are membrane components and are present in all the living organisms kingdoms, i.e. bacteria, plants and animals. They have important roles as energy source and markers for the cellular recognition and communication. Structurally they can be divided in different families like glycoglycerolipids, with acylated glycerol attached to the carbohydrate part, glycosphingolipids with an acylated sphingosine (ceramide) and isoprenoid glycosides, with a terpene alcohol as aglycon. All this kind of molecules are characterized by very important biological activities. ${ }^{1,2}$ There is a big interest in both intracellular and extracellular glycolipids. In the last years, members of the family, especially galactosyldiacylglycerols and ceramides, have attracted the interest of the bio-medical community for their properties in cancer chemoprevention ${ }^{3}$ and immunology; ${ }^{4}$ on the other side sulphoquinovosyldiacylglycerols are characterized by other extensive biological properties as antitumoral, ${ }^{5}$ HIV-RT inhibition, ${ }^{5,6}$ AIDS-antiviral $^{7}$ and DNA polymerase $\alpha$ and $\beta$ inhibition. ${ }^{8}$ The possibility to get these compounds by chemical synthesis is important cause the difficulty in their isolation and purification from natural sources; the synthetic approach can give the opportunity to study the potential activity of these molecules whose structure could be modified in different ways to run SAR analysis. Here we discuss a simple and versatile strategy for the synthesis of galactosyldiacylglycerols.

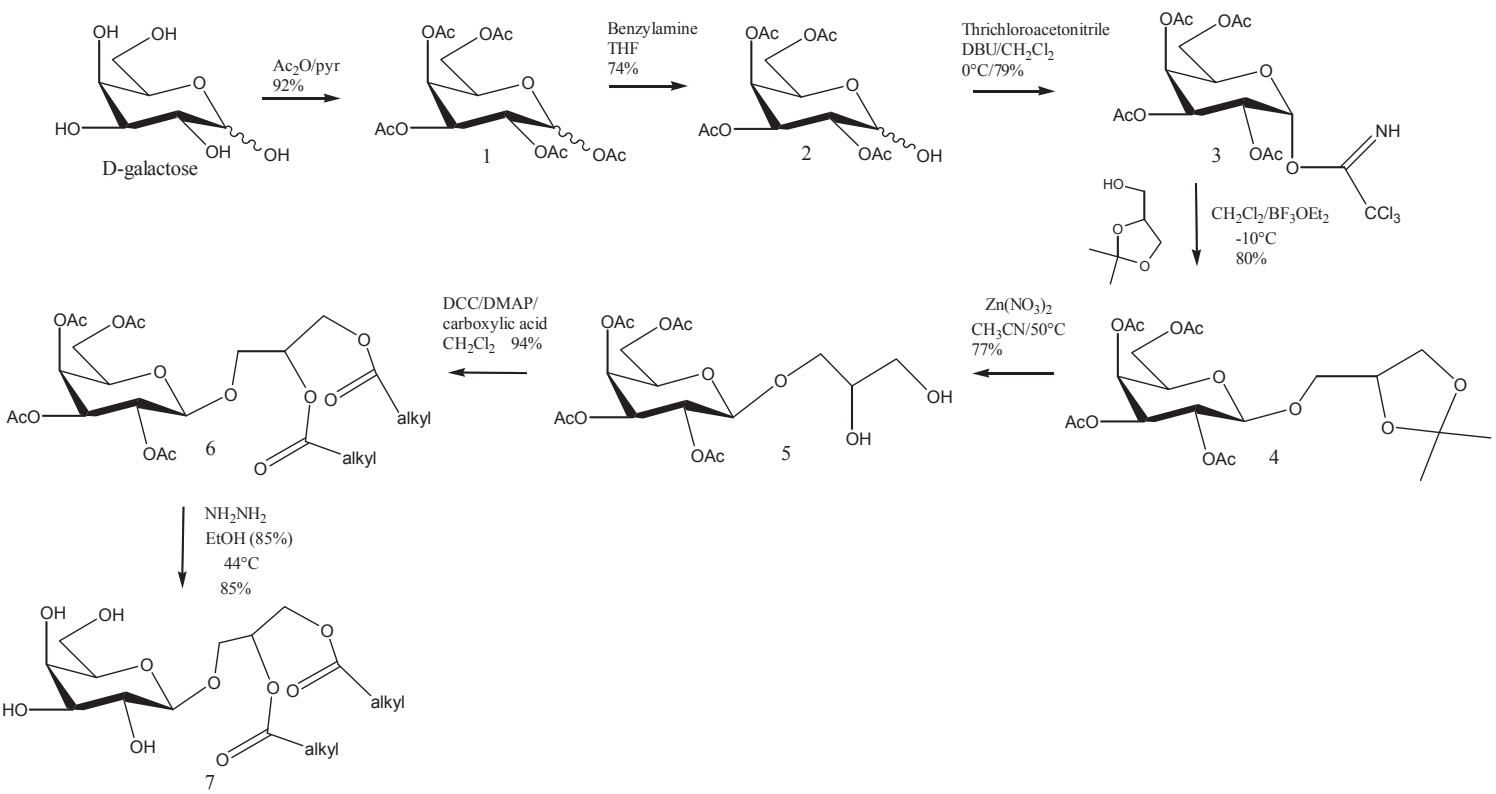

Scheme 1. Synthesis of $\beta$ - galactosyl-1,2-diacylglycerols

Synthetic strategy (Scheme 1). D-galactose was acetylated (1) and the subsequent anomeric deacetylation was performed by benzylamine to get $\mathbf{2}$. The hydroxyl anomeric function was derivatized by trichloroacetonitrile in presence of 1,8-Diazabicyclo[5.4.0] undec-7-ene (DBU); the trichloroacetimidate obtained (3) was coupled with glycerol 1,2-acetonide (derived by acetonidation of glycerol with 2,2-dimethoxypropane and $p$-toluensulfonic acid in $N, N$-dimethylformamide) to get 4 . After the removal of the isopropylidene protecting group with zinc nitrate in acethonitrile, we obtained compound $\mathbf{5}$ that was acylated with the carboxylic acids (i.e. linolenic acid) in presence of diciclohexylcarbodiimide and triethylamine; the final step, the deacetylation of $\mathbf{6}$, was very important cause the presence 
of acyl unsatured moiety that should be unaltered using less amount (in comparison of literature conditions ${ }^{9}$ ) of hydrazine hydrate at $44^{\circ} \mathrm{C}$ to get 7 . Using more amount of hydrazine hydrate and increasing the temperature until $55^{\circ} \mathrm{C}$, saturation of acyl double bonds happened, and on the other side, partial deacylation yielded to the $\beta$-galactosyl-monoacylglycerol $(15 \%)$ in which the linolenyl residue was on the primary position of the glycerol part.

Conclusions. Synthesis of $\beta$-galacto-1,2-diacylglycerols is achieved by a versatile and simple procedure based on the trichloroacetimidate methodology and peracetate sugar precursors. The methodology is tested through stereoselective preparation of $\beta$-galacto-lipids representing compounds that have been recently gained great interest as triggers of immune system response. The synthetic strategy is designed to obtain regio- and stereo isomers including derivatives containing poly-unsaturated fatty acids.

Acknowledments. Academy of Sciences (Moldova) and CNR (Italy) are acknowledged for financial support (bilateral project Kulcitki/Gavagnin "Novel approaches for the synthesis of optically active cannabinoids with relevant biological activity and therapeutical potential").

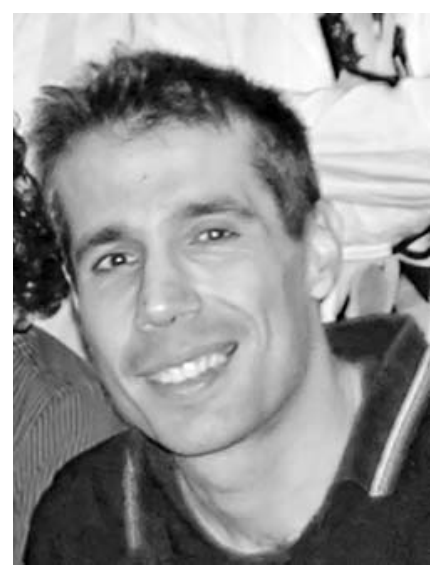

Dr. Emiliano Manzo was born in 1973. He graduated from University of Naples (Italy)Federico II in 1996 and obtained his Ph.D. degree in 2001 from University of Naples (Italy)Federico II, Chemistry Department, under the supervision of Professor Michelangelo Parrilli; in 2001 he was researcher in the Institute of Biomolecular Chemistry (Pozzuoli-Naples) of the National Research Council (CNR), where he works on the chemical synthesis of marine natural compounds and on the isolation from marine invertebrates of new compounds with important biological activity and with potential pharmacological applications. He is the author of more than 45 scientific papers and three patents.

\section{References}

[1]. Oshida,Y.; Yamada,S.; Matsunaga, K.; Moriya, T.; Ohizumi, Y., J.Nat.Prod., 1994, 57(4), 534-536.

[2]. Nakato,K.; Guo,C-T; Matsufuji,M.; Yoshimoto, A.; Inagaki, M.; Higuchi, R.; Suzuki, Y. J. Biochem., 2000, 127, 191-198.

[3]. a) Matsubara, K.; Matsumoto, H.; Mizushina, Y.; Mori, M.; Nakajima, N.; Fuchigami, M.; Yoshida, H.; Hada, T. Oncol.Rep., 2005, 14, 157-160.; b) Shirahashi, H.; Murakami, N.; Watanabe, M.; Nagatsu, A.; Sakakibara, J.; Tokuda, H.; Nishino, H.; Iwashima, A. Chem.Pharm.Bull., 1993, 41, 1664-1666; c) Colombo, D.; Scala, A.; Taiano, I.M.; Toma, L.; Roncheti, F.; Tokuda, H.; Nishino, H.; Sakakibara, J. Bioorg.Med.Chem.Lett, 1996, 6, 1187-1190.; d) Colombo, D.; Franchini, L.; Toma, L.; Ronchetti, F.; Nakabe, N.; Konoshima, T.; Nishino, H.; Tokuda, H. Eur.J.Med.Chem, 2005, 40, 69-.74; e) Nagatsu, A.; Watanabe, M.; Ikemoto, K.; Hashimoto, M.; Murakami, N.; Sakakibara, J.; Tokuda, H.; Nishino, H.; Iwashima, A.; YAzawa, K. Bioorg. Med. Chem. Lett., 1994, 41, 1619-1622.

[4]. Di Libero, G.; Mori, L. Nature Rev. 2005, 5, 485- 496; Di libero, G. Science 2004, 303, 485-486.

[5]. Sahara, H.; Ishikawa, M.; Takahaschi, N.; Ohtani, S.; Sato, N.; Gasa, S.; Akino, T.; Kikuchi, K. J. Cancer, 1997, $75,324-332$.

[6]. Ohta, K.; Mizushina, Y.; Hirata, N.; Takemura, M.; Sugawara, F.; Matsukage, A.; Yoshida, S.; Sakaguchi, K. Chem. Pharm. Bull., 1998, 46, 684;. Ishiyama, H.; Ishibashi, M.; Ogawa, A.; Yoshida, S.; Kobayashi, J. J. Org. Chem., 1997, 62, 3831-3836; Sun, D.A.; Deng, J.Z.; Shelley, R.S.; Sidney, M.H. J. Am. Chem. Soc., 1999, 121, 6120-6124; Chen, J.; Zhang, Y.H.; Wang, L.K.; Steven, J.S.; Angela, M.S.; Sidney, M.H. J. Chem. Soc., Chem. Commun., 1998, 2769-2770.; Deng, J.Z.; Sun, D.A.; Shelley, R.S.; Sidney, M.H.; Ronald, L.C.; John, R.E. J. Chem. Soc., Perkin Trans. 1, 1999, 1147-1149.; Ma, J.; Shelley, R.S.; Sidney, M.H. J. Nat. Prod., 1999, 62, 1660-1663; Deng, J.Z.; Shelley, R.S.; Sidney, M.H. J. Nat. Prod., 1999, 62, 1624-1626; Sun, D.A.; Shelley, R.S.; Edward, P.L.; Sidney, M.H. J. Nat. Prod., 1999, 62, 1110-1113; Deng, J.Z.; Shelley, R.S.; Sidney, M.H.; Carl, F.I.; Mark, E.H. J. Nat. Prod., 1999, 62, 1000-1002; Deng, J.Z.; Shelley, R.S.; Sidney, M.H. J. Nat. Prod., 1999, 62, 477-480.; Golik, J.; Dickey, J.K.; Todderud, G.; Lee, D.; Alford, J.; Huang, S.; Klohr, S.; Eustice, D.; Aruffo, A.; 
Agler, M.L. J. Nat. Prod., 1997, 60, 387-389;. Loya, S.; Reshef, V.; Mizrachi, E.; Silberstein, C.; Rachamin, Y.; Carmeli, S.; Hizi, A. J. Nat. Prod., 1998, 61, 891-895.

[7]. Gustafson, K.R.; Cardellina II, J.H.; Fuller, R.W.; Weislow, O.S.; Kiser, R.F.; Snader, K.M.; Patterson, G.M.L.; Boyd, M.R. J. Nat. Can. Inst., 1989, 81, 1254-1258.

[8]. Mizushina, Y.; Watanabe, I.; Ohta, K.; Takemura, M.; Sahara, M.; Takahashi, N.; Gasa, S.; Sugawara, F.; Matsukage, A.; Yoshida, S.; Sakaguchi, K. Biochem. Pharmacol., 1998, 55, 537; Ohta, K.; Mizushina, Y.; Hirata, N.; Sugawara, F.; Matsukage, A.; Yoshida, S.; Sakaguchi, K. Chem. Pahrm. Bull., 1999, 46, 684; Hanashima, S.; Mizushina, Y.; Takayuki, Y.; Keisuke, U.; Takahashi, S.; Koshino, Y.; Sahara, H.; Sakaguchi, K., Sugawara, F. Tetrahedron Lett., 1999, 46, 684.

[9]. Janwitayanuchit, W.; Suwanborirux, K.; Patarapanich, C.; Pummangura, S.; Lipipun, V.; Vilaivan, T. Phytochemistry., 2003, 64, 1253-1264. 